\title{
Penyebab TerJadinya Justifikasi Teknis Pada PekerJaAn Jalan Di Sumatera BARAT
}

\author{
OCCURRENCE CAUSES OF TECHNICAL JUSTIFICATION ON ROAD WORKS IN SUMATRA BARAT \\ ${ }^{1}$ Eva Rita, ${ }^{2}$ Nasfryzal Carlo, ${ }^{3}$ Hendri Warman, ${ }^{4}$ Yoka Mahendra \\ 1, 2, 3 Dosen Tetap Teknik Sipil Universitas Bung Hatta, Jl. Sumatra Ulakkarang, Padang \\ ${ }^{4}$ Alumni S2 Teknik Sipil Universitas Bung Hatta, Jl. Sumtra Ulakkarng, Padag \\ Email: ${ }^{1}$ carlovana113@ymail.com, ${ }^{2}$ carlo@bunghatta.ac.id, ${ }^{3}$ warman_hendri@yahoo.com, \\ ${ }^{4}$ mahendra_haviz@yahoo.co.id
}

\begin{abstract}
Abstrak. In development and reconstruction of roads frequent changes work items, affecting the cost, turnaround time and quality of work. In order to determine what factors cause of the technical justification has conducted a study of eight packages of road construction and eight packages of reconstruction road capacity of West Sumatra in the unit Implementation of National Road Region I and Region II under the National Road Agency of West Sumatera Province. The work packages studied was the work conducted in 2009 to 2015. The method used was descriptiveevaluative research. Results of the study found the 7 causal factors do technical justification that the initial design of the contract is not in accordance with the results of the engineering field, not taking into account the design life of the road, , has not been calculated in detail the volume and the price for each item of work, do not pay attention to Standard Directorate general of Highways Ministry of public Works, the land is not available when the project is implemented, the results of field surveys for planning is not complete, and the occurrence of overlapping projects between the state and local budgets. To eliminate the occurrence of increased costs due to technical justification is necessary to complete the field survey by calculating in detail the volume and the price for each work item.
\end{abstract}

Keywords: road construction, reconstruction/upgrading of roads, technical justification

\begin{abstract}
Abstrak. Pada proyek pembangunan dan rekontruksi sering terjadi perubahan item pekerjaan, sehingga berpengaruh terhadap biaya, waktu penyelesaian dan kualitas pekerjaan. Guna mengetahui faktor penyebab terjadinya justifikasi teknis telah dilakukan kajian terhadap 8 paket pekerjaan pembangunan jalan dan 8 paket rekonstruksi jalan Sumatera Barat di lingkungan Satuan Kerja Pelaksanaan Jalan Nasional Wilayah I dan Wilayah II dibawah Koordinasi Balai Besar Jalan Nasional di Provinsi Sumatera Barat. Paket pekerjaan yang diteliti adalah pekerjaan yang dilaksanakan pada tahun 2009-2015. Metode penelitian yang digunakan adalah deskriptif evaluatif. Ditemukan 7 faktor penyebab dilakukan justifikasi teknis yaitu desain awal pada kontrak tidak sesuai dengan hasil rekayasa lapangan, tidak memperhitungkan umur rencana jalan, belum memperhitungkan secara detail volume dan harga untuk setiap item pekerjaan, tidak memperhatikan Standard Direktorat Jenderal Bina Marga Departemen Pekerjaan umum, lahan belum tersedia ketika proyek dilaksanakan, hasil survei lapangan untuk perencanaan tidak lengkap, dan terjadinya tumpang tindih proyek antara APBN dan APBD. Guna mengeliminasi terjadinya peningkatan biaya akibat justifikasi teknis perlu dilakukan survei lapangan yang lengkap dengan menghitung secara detail volume dan harga untuk setiap item pekerjaan.
\end{abstract}

Kata kunci: pembangunan jalan, rekonstruksi/peningkatan jalan, justifikasi teknis 


\section{Pendahuluan}

Pembangunan prasarana transportasi, jalan dan jembatan diperlukan untuk menunjang kemajuan perekonomian suatu daerah. Lancarnya arus lalu lintas akan menyebabkan distribusi barang dan jasa dapat berjalan dengan optimal. Pembangunan jalan di provinsi Sumatera Barat dilaksanakan dibawah koordinasi Balai Besar Jalan Nasional. Pembangunan jalan berupa pembangunan jalan baru atau meningkatkan fungsi kapasitas jalan seperti bangunan pelengkap untuk prasarana lalu lintas. Selain itu untuk meningkatkan kondisi jalan sesuai dengan laju pertumbuhan dilakukan juga pemeliharaan jalan dan rekonstruksi jalan. Rekonstruksi jalan adalah peningkatan struktur yang merupakan kegiatan penanganan untuk dapat meningkatkan kemampuan bagian ruas jalan yang dalam kondisi rusak berat agar bagian jalan tersebut mempunyai kondisi mantap kembali sesuai dengan umur rencana yang ditetapkan (Permen PU, 2011).

Pelaksanaan pekerjaan jalan yang baik membutuhkan perencanaan yang tepat, akurat dan sesuai dengan kondisi lapangan. Sangat sedikit sekali bisa ditemukan suatu proyek yang tidak mengalami perubahan pada keseluruhan tahapan proyek (Barrie and Paulson, 1992). Pelaksanaan pembangunan proyek Jalan Nasional Provinsi Sumatera Barat masih sering mengelami perubahan lingkup pekerjaan pada penyelenggaraan kegiatan dan berdampak adanya perubahan konstruksi yang mempengaruhi waktu pelaksanaan, biaya, dan kualitas pekerjaan. Rata-rata pada pelaksanaan pembangunan proyek Jalan Nasional Provinsi Sumatera Barat mengalami justifikasi teknis, ini disebabkan berbagai faktor seperti Contract Change Oder (CCO), perbedaan perencanaan awal dengan kondisi di lapangan, kebijakan pemerintah, dan lain - lain. Perubahan dapat terjadi pada awal, pertengahan sampai pada akhir pekerjaan konstruksi proyek (Nunnaly, 1993). Pekerjaan jalan perubahan kontrak kerja sering terjadi pada awal proyek. Perubahan ini umumnya berupa penambahan dan pengurangan lingkup proyek setelah kontrak di tanda tangani (Soeharto, 2001).

Proyek jalan terdiri dari lingkup pekerjaan yang spesifik, periode dari performa hasil proyek yang telah ditetapkan dan biaya anggaran proyek, dimana dapat mengalami perubahan selama masa proyek berlangsung. Akibat dari perubahan - perubahan yang tidak terencana dalam proyek konstruksi dapat menyebabkan pekerjaan tambah di luar yang diharapkan (Chen dan Hsu, 2007). Perubahan tersebut otomatis akan mempengaruhi volume, waktu pelaksanaan dan biaya yang dibutuhkan.

Soekirno dkk (2007) dan Idzrunida (2013), menemukan beberapa masalah dalam pekerjaan jalan dan jembatan antara lain adanya perubahan lingkup pekerjaaan di tengah jalan, penundaan jadual pekerjaan, adanya penambahan biaya pengadaan sehinga menyebabkan terjadinya perubahan kontrak terhadap pekerjaan. Syahruddin (2015), mengungkapan bahwa pelaksanaan jalan Nasional Wilayah I Provinsi Sumatera Barat, pada tahun 2011 sampai dengan tahun 2013 tedapat 63 paket mengalami keterlambatan yang disebabkan oleh perubahan kontrak kerja (contrack change order).

Beberapa faktor penyebab terjadi perubahan kontrak kerja (change order) adalah adanya keinginan dari pemilik untuk merubah suatu spesifikasi pekerjaan sesudah kontrak ditanda tangani antara keinginan untuk mempercepat pekerjaan karena kebutuhan pasar, publik, dan pertimbangan politik. Faktor yang lain adalah suatu keadaan yang tak terduga diluar kekuatan pemilik maupun kontraktor seperti bercana alam, huruhara dan keadaan perang (Sapulette, 2009). Menurut Bolin (2015), penyebab change order adalah perubahan design, perubahan kondisi lapangan, perubahan lingkup dan item pekerjaan, perubahan anggaran, percepatan waktu pelaksanaan dan 
penyesuaian harga. Perubahan pekerjaan pada tahap pelaksanaan dapat berupa penambahan, pengurangan, bahkan penggantian lingkup pekerjaan yang telah disepakati bersama dalam kontrak kerja awal. Perubahan lain dapat terjadi saat pelaksanaan proyek, berupa adanya perpanjangan waktu (time extension), penambahan item pekerjaan, ataupun pengurangan nilai kontrak sebagai akibat adanya revisi desain (Levy, 2002).

Berdasarkan Perpres nomor 54 tahun 2010, ketentuan perubahan kontrak dapat dilakukan apabila terdapat perbedaan antara kondisi lapangan pada saat pelaksanaan dengan gambar dan atau spesifikasi teknis yang ditentukan dalam dokumen kontrak, adanya pekerjaan tambah yang tidak melebihi $10 \%$ dari harga dalam perjanjian kontrak, dan tersedianya anggaran untuk itu. Berkaitan dengan perubahan kontrak pada pelaksanaan proyek Jalan Nasional Sumatera Barat yang mengakibatkan terjadinya perubahan volume dan item pekerjaan serta berdampak paa biaya dan waktu, maka dilakukan penelitian untuk mengetahui faktor apa sajakah yang menyebabkan terjadinya justifikasi teknis pada proyek pembangunan dan rekonstruksi/peningkatan kapasitas jalan di Provinsi Sumatera Barat.

\section{Metoda Penelitian}

Metode penelitian digunakan metoda deskriptif evaluatif. Analisis dilakukan terhadap 8 pekerjaan pembangunan jalan dan 8 pekerjaan rekonstruksi/peningkatann di Sumatera Barat yang dikerjakan semenjak tahun 2009 hingga tahun 2015. Pekerjaan ini dilakukan dibawah koordinasi Proyek Pembangunan Jalan Nasional Wilayah I dan II Provinsi Sumatera Barat dengan nilai kontrak diatas Rp 2,5 milyar. Penelitiaan ini dilakukan dengan melakukan evaluasi dan tabulasi terhadap data-data yang diperoleh dari dokumen kontrak awal, dokumen justifikasi teknis, dan perubahan kontrak (addendum) setiap pekerjaan.

\section{Hasil dan Pembahasan}

Hasil analisis terhadap paket pembangunan jalan didapati justififikasi teknis disebabkan oleh pertama, desain awal pada kontrak tidak sesuai dengan hasil rekayasa lapangan pada saat pelaksanaan akan dilakukan. Pelaksaaan pembangunan yang sudah direncanakan kadang kala baru dapat terlaksana setelah 4-5 tahun kemudian, sehingga telah terjadi perubahan kondisi di lapangan. Namun untuk pekerjaan rekonstruksi/peningkatan jalan tidak memerlukan waktu lama untuk dilaksanakan setelah perencanaan dilakukan karena jika tidak dilaksanakan segera akan menyebabkan jalan yang akan direkontruksi semakin bertambah rusak. Kondisi ini akan mempengaruhi biaya dan waktu pekerjaan (Lee, 2008).

Penyebab kedua adalah tidak memperhitungkan umur rencana jalan. Seharusnya untuk pembangunan jalan sudah memperperhitungkan umur rencana jalan sesuai peruntukannya. Umur rencana jalan untuk jalan arteri dan kolektor adalah 10 thun, sedangkan untuk jalan lokal umur rencana adalah 5 tahun. Untuk rekonstruksi struktural jalan harusnya dilakukan pada saat habisnya umur rencana jalan, tetapi didapati kondisi lalu lintas yang melintasi lokasi pekerjaan ini banyak mempunyai beban (MST) melebihi dari yang telah ditetapkan sehingga mengakibatkan berkurangnya umur rencana jalan sesuai dengan yang telah ditetapkan.

Penyebab ketiga, belum diperhitungkan secara detail setiap item pekerjaan sehingga terjadi perubahan harga dan nilai satuan. Perhitungan volume dan harga pada kontrak oleh pengguna disesuaikan dengan ketersediaan anggaran, sementara ketika 
rekayasa lapangan dilakukan ternyata volume beberapa item pekerjaan tidak sama lagi bahkan sering bertambah. Pertambahan volume menyebabkan kenaikan harga sehingga akhirnya kontrak perlu dirubah melalui kajian justifikasi teknis. Pada pekerjaan rekontruksi/peningkatan juga terjadi perubahan kontrak karena perhitungan volume tidak detil sesuai item pekerjaan yang akan dilaksanakan.

Keempat, adalah ketika perencanaan tidak memperhatikan Standard Direktorat Jenderal Bina Marga Departemen Pekerjaan umum. Pembangunan jalan provinsi dengan ROW jalan pada saat ini (exsisting road) dengan lebar 4,5 m tidak memenuhi standar geometrik dan kapasitas jalan sesuai standar yang di isyaratkan oleh Direktorat Jendral Bina Marga Departemen Pekerjaan umum. Berdasarkan Tata cara Perencanaan Geometrik antar kota 038/TBM/1997, disarankan untuk jalan arteri kls I, II, IIIA, lebar lajur 3,5-3,6 $\mathrm{m}$ dengan lebar bahu jalan tanpa trotoar $2 \mathrm{~m}-2.5 \mathrm{~m}$ dan lebar bahu jalan ada trotoar 0,5m-1m. Sesuai Undang Undang No. 38 Tahun 2004 tentang Jalan dan Peraturan Pemerintah No. 34 Tahun 2006 tentang Jalan, lebar badan jalan untuk jalan lokal/kabupaten adalah 7,5 meter dengan lebar jalur lalu lintas adalah 5,5 meter, sedangkan lebar badan jalan untuk jalan provinsi adalah 9 meter dengan lebar jalur lalu lintas adalah 7 meter.

Penyebab ke lima, hasil survei lapangan tidak lengkap sehingga hasil perencanaan dalam kontrak tidak bisa langsung dilaksanakan. Survei dilapangan diperlukan untuk pengumpulan informasi-informasi yang akurat yang diperlukan untuk mengetahui kuantitas/volume pekerjaan yang dibutuhkan di lapangan. Ada beberapa hal yang menjadi dasar pertimbangan perencanaan adalah klasifikasi jalan, karakteristik jalan, karaktrtistik lalu lintas, dampak lingkungan, ekonomi dan keselamatan lalu lintas (Sugeng, 2014). sedangkan untuk penentuan program penanganan jalan bisa berpedoman pada Permen PUPR 47 Tahun 2015. Pada pekerjaan rekontruksi jalan survei lapangan juga mempengaruhi ketepatan perencanaan dan pelaksanaan. Apabila terjadi kesalahan dalam pengukuran (survei lapangan) dapat menyebabkan kegagalan proyek (Suswanto (2014).

Penyebab ke enam adalah lahan belum tersedia ketika proyek dilaksanakan. Terlambatnya dimulai pekerjaan disebabkan lahan belum siap dipakai karena penyelesain pembebasan lahan terlambat. Ini sering terjadi akibat kurangnya koordinasi antara pemerintah provinsi dengan pemerintah kabupten/kota. Seringkali pembangunan jalan oleh provinsi tidak sesuai dengan perencanaan pembangunan jalan oleh kabupaten/kota, sehingga komitmen pembebasan lahan sering tidak terlaksana tepat waktu karena program dan anggaran daerah tidak tersedia untuk itu. Sugeng (2014) mengatakan bahwa pada tahap pra konstruksi adalah kegiatan pembebasan lahan akan berdampak penting kepada persepsi masyarakat. Apalagi di Sumatera Barat banyak terdapat tanah ulayat dimana untuk pembebasan harus mendapat persetujuan pemilik/ahli waris dari kaum.

Penyebab terakhir adalah terjadinya tumpang tindih pembiayaan poyek antara APBN dan APBD. Sering terjadi proyek yang tumpang tindih antara pemerintah pusat dan provinsi atau pemerintah provinsi dengan pemerintah kabupaten/kota. Ini akibat kurangnya koordinasi antara pemerintah pusat dengan provinsi dan provinsi dengan kabupaten/kota dalam melakukan pengusulan program dan anggaran. Untuk pengusulan alokasi dana APBN harus berdasarkan usulan daerah. Untuk perencanaan pembangunan Nasional diatur pada PP No 40 Tahun 2006 tentang tata cara penyusunan rencana pembangunan nasional dan Permendagri Nomor 54 Tahun 2010 tentang pelaksanaan Peraturan Pemerintah nomor 8 tentang Tahapan, Tatacara Penyusunan, Pengendalian, dan Evaluasi Perencanaan Pembangunan Daerah. 


\section{Kesimpulan}

Faktor-faktor penyebab terjadinya justifikasi teknis pada proyek jalan adalah sebagai berikut : desain awal pada kontrak tidak sesuai dengan hasil rekayasa lapangan pada saat pelaksanaan akan dilakukan, tidak memperhitungkan umur rencana jalan, belum di perhitungkan secara detail untuk setiap item pekerjaan, tidak memperhatikan standard direktorat jenderal bina marga departemen pekerjaan umum, lahan belum tersedia ketika proyek dilaksanakan, hasil survey lapangan untuk perencanaan tidak lengkap, terjadinya tumpang tindih proyek antara APBN dan APBD, kaji ulang terhadap penangan ruas jalan sehubungan kapasitas lalu lintas .Faktor yang sama menyebabkan justifikasi teknis pada proyek pembangunan jalan dan pekerjaan rekonstruksi adalah desain awal pada kontrak tidak sesuai dengan hasil rekayasa lapangan pada saat pelaksanaan akan dilakukan, belum di perhitungkan secara detail untuk setiap item pekerjaan dan desain yang tidak lengkap, kurang lengkapnya desain dapat menjadi hambatan pelaksanaan suatu proyek hasil survey lapangan untuk perencanaan tidak lengkap.

Perlu dilakukan perencanaan pembangunan sesuai rencana tata ruang wilayah (RT/RW) provinsi Sumatera Barat sehingga terjadi sinkronisasi pembangunan antara provinsi, kabupaten dan kota dan memperjelas penggunaan lahan dan pembebasan lahan. Untuk pemograman dan anggaran proyek hendaklah dilakukan koordinasi yang baik antara pusat, provinsi, kabupaten, dan kota serta mempedomani dan mengikuti peraturan, standard dan manual desain perkerasan jalan yang tersedia. Disarankan bagi perencana untuk apat melakukan survei lapangan yang lebih teliti sehingga hasil perencanaan jalan dapat dilaksanakan tanpa terjadi kegagalan konstruksi.

\section{Ucapan Terima Kasih}

\section{Daftar pustaka}

Bappenas (2006), PP No 40 Tahun 2006 tentang tata cara penyusunan Rencana Pembangunan Nasional.

Chen, J.-H., \& Hsu, S. (2007). Hybrid ANN-CBR Model for Disputed Change Orders in Construction Project. Automation in Contruction, Vol. 17, p.56-64.

Idzurnida Ismail (2013). Faktor Penyebab Keterlambatan Proyek Konstruksi dan Pencegahannya, Jurnal Momentum Vol. 14 No.1. Februari 2013.ISSN : 1693 $752 X$.

Kemendagri (2010), Permendagri Nomor 54 Tahun 2010 Tentang Pelaksanaan Peraturan Pemerintah Nomor 8 Tentang Tahapan, Tatacara Penyusunan, Pengendalian, dan Evaluasi Perencanaan Pembangunan Daerah.

Lee, J.-K. (2008). Cost Overrun and Cause in Korean Social Overhead Capital Projects: Road, Rail, Airports, and Ports. Journal of Urban Planning and Development. Vol. 134, p.59-62.

Levy, Sidney M (2002). Project Management in Construction. New York: Mc GrawHill.

Suswanto, O.T.V (2014) . Penyebab dan Cara Mengatasi Kegagalan Proyek Konstruski pada Tahap Perencanaan hingga Pelaksanaan di Daerah Yogyakarta. Skripsi S1. UAJY. 
Sapulette,W.(2009). Faktor Penyebab dan Pengaruh Change Order Pada Proyek Infrastruktur dan Bangunan Gedung di Ambon. Jurnal Teknologi, Vol 6 No 2, P 627-633.

Soekirno, P., Wirahadikusumah,R., Abduh, M., (2007). Sengketa dalam Penyelenggaraan Proyek Konstruksi di Indonesia, Buku Referensi, Konstruksi: Industri, Pengelolaan, dan Rekayasa, Penerbit ITB, ISBN 979-3507-98-5

Subrimen, (2015). Analisis Penyebab Keterlambatan Penyelesaian Proyek Konstruksi Jalan Nasional di Kabupaten Pesisir Selatan, Tesis, Universitas Bung Hatta, Padang.

Sugeng, M (2014). Dasar Perencanaan Jalan, Survai dan Data Pendukung. https://independent. academia.edu/maryonosugeng. Diakses 20 September 2016)

Syahruddin, R. (2015). Analisis Kualitas Pekerjaan Pada Kontraktor Gred 5, Gred 6, dan Gred 7 Pada Satuan Kerja Pelaksanaan Jalan Nasional Wilayah I Provinsi Sumatera Barat, Tesis, Universitas Bung Hatta, Padang. 